\title{
PERESTROIKAN TAITEILIJAPOLVI Moskovassa
}

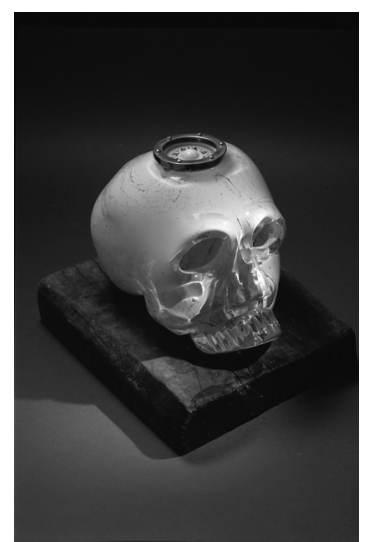

Andrei Filippov: Hyvin orientoitunut kallo, Murano, 2006.

Moskovassa Furmannij-kujalla sijainneessa läpiränsistyneessä kerrostalossa työskenteli 1980luvun lopulla kymmeniä taiteilijoita, joista monet testasivat uusia käsitteitään ja taiteellisia ideoitaan vapaissa kokeissaan. Perestroikan ajan neuvostoliittolaisessa taiteessa marxilais-leniniläisen ideologian dekonstruktio oli keskeistä aineistoa ja aiheistoa.Teoksista välittyi neuvostoimperiumin moraalinen ja poliittinen eroosio hilpeänä ja älykkäänä karnevaalina.

Talossa jakoi yhteisen työhuoneen monien ohella nuorten, 1960-luvun alussa syntyneiden taiteilijoiden, "post-post-konseptualistien" joukko: Jurij Albert, Andrei Filippov, Sven Gundlah, Sergei Mironenko, Vladimir Mironenko, Vadim Zaharov, Konstantin Zvezdotshetov ja Larisa Zvezdotshetova. Kutsukaamme heitä Furmannij-ryhmäksi, johon lukeutui myös Andrei Roiter, vaikka hänen studionsa sijaitsikin toisaalla. Ryhmällä oli suuri vaikutus Neuvostoliiton viimeisten vuosien taiteeseen, ja kaikki jäsenet ovat eri tavoin mukana myös Venäjän nykytaiteessa. Taidekeräilijä Pekka Halosen Eroosio-kokoelma Suomessa on ryhmän taiteilijoiden mukaan edustavin kokonaisuus heidän työstään 1980-luvun lopulta.

Furmannij-ryhmän taide oli perestroikan ajan taidetta mutta ei perestroikan taidetta. Taiteilijat eivät olleet presidentti Gorbatshovin uudistusohjelman sotureita. Päinvastoin he kommentoivat kriittisesti ja myös kyseenalaistivat ylhäältä johdettua yhteiskunnallista muutospolitiikkaa. Filippoville myytti Moskovasta kolmantena Roomana oli hersyvä fabuloinnin lähde, Zvezdotshetov leikitteli tarinalla omituisesta kadonneesta Perdon valtakunnasta Neuvostoliiton vertauskuvana ja Zvezdosthetova pyrki määrittelemään venäläisyyttä. Albertia kiehtoi rappiotaiteen käsite ironisine ulottuvuuksineen. Mironenkot ja Roiter pureutuivat perestroikan ideologiaan ja sosialismin merkkijärjestelmiin. Elämän mielekkyys oli Zaharovin taiteen kysymys.

Nykyisin osa ryhmän taiteilijoista elää Moskovassa, osa Länsi-Euroopassa. Saksassa asuva Albert keskittyy työssään taidefilosofisiin ongelmiin. Sergei Mironenko, joka toimii nyt ensisijassa muotoilijana, panee kauneuden haasteen etusijalle. Zevzdotshetov jatkaa Venäjän lähihistorian metaforista kirjoittamista sarjakuvamaisin keinoin. Liikkuvainen Gundlah on puolestaan tällä erää pankinjohtaja. Putinin Venäjään useimmat heistä suhtautuvat karsastaen, mutta moskovalainen Filippov ei kuitenkaan halua kiistää saavutetun vakauden arvoa. Hänen uusissa montaaseissaan jättiläismäinen sahanterä työntyy esiin Kremlin muurin takaa. Monumentaalisena veistoksena terä, joka toistaa Kremlin muurinharjan italialaisperäistä hammastusta, sojottaa Istanbulin kaupunkimaisemassa tai palmujen keskellä Miamissa. Onko kyse kolmannen Rooman uudesta vallantunteesta vaiko sen ironisesta ravistelusta? 